\title{
Strategic Overshooting in National Council Elections
}

\author{
Romain Lachat and Peter Selb \\ University of Zurich and University of Konstanz
}

\begin{abstract}
The Swiss party system has become strongly polarized over the last decade, following the rise of the Swiss People's Party and the electoral losses of center parties. This article suggests that these developments are, at least in part, a consequence of strategic behaviour among voters. As the government policy is the result of institutionalized multiparty bargaining, voters have incentives to compensate for this watering-down by supporting parties whose positions are more extreme than their own. This article empirically tests extent and conditions of compensatory voting in the 2007 National Council Elections using Selects survey data. Our results suggest that compensatory voting generally outweighs voting based on ideological proximity and increases with rising district magnitude.
\end{abstract}

KeYwords: Spatial Models • Issue Voting • Compensatory Voting

\section{Introduction}

The Swiss political landscape has been marked by important developments in the last two decades. The Swiss People's Party (SVP) has made impressive electoral gains since the early 1990s. Long the junior partner of the governing coalition, it now has the largest vote share in the National Council (lower house). This status was confirmed in the 2007 elections, where the SVP could further expand its lead. At the same time, the major left-wing party, the Social-Democrats (SPS), could hold to its vote share of the late 1980s or improve upon it, while the Greens have made important gains. One can thus observe the formation of two poles, with strongly divergent ideological positions. These party blocs have strengthened at the expense of the major centre and centre-right parties, the Christian-Democrats (CVP) and the Liberals (FDP), which have suffered significant electoral losses in recent elections. 
What do these developments tell us about the motivations of the Swiss electorate? A common interpretation is that voters, too, have become more polarized. The relatively weak results of the centre parties in recent elections would be a direct reflection of the comparatively high degree of ideological polarization among Swiss citizens. Large numbers of voters should share the ideological position of the SVP and of the SPS or the Greens, respectively. Given the magnitude and speed of the changes in the party landscape, this would mean that the ideological preferences of Swiss voters have been transformed to an impressive degree over a relatively short period of time.

This article suggests a different interpretation. The consensual character of Swiss democracy means that any party has only a limited influence over the government position. Voters, we argue, may respond to these institutional constraints by supporting parties that are more extreme than their own preferences. This "compensatory voting" is a form of strategic voting guided by the expected change in the government's position. Consider for example the situation voters faced in the 2007 election. The SVP's win of a second governmental seat after the 2003 elections shifted the government position rightwards. But not to the point of bringing the government position in line with the SVP position. This was a favourable outcome for voters who were on the right of the previous government, without being as far right as the SVP. These voters may be incited to support the SVP in 2007, in order to maintain the new status quo, rather than supporting a moderate right-wing party, which may be closer to their own position, but which entails a risk of the government position shifting back leftwards.

This study examines the extent of this type of strategic voting in the 2007 federal elections. The next section introduces compensatory voting in more detail. It also suggests that the strength of compensatory voting should be conditional on electoral district magnitude. Then, we present the operationalization of our concepts and discuss the estimation of the statistical model, which combines characteristics of citizens, parties, and cantons. This is followed by the presentation and discussion of the empirical results. We find strong evidence for compensatory voting in the Swiss electorate and show that its frequency increases with district magnitude. The article concludes by discussing some implications of our findings. 


\section{National- and District Level Incentives for Voting Strategically}

Many decision theoretic models of voting conceive of voters and parties as being located on a single latent policy continuum ranging from, say, left to right (e.g., Cox 1997). In general, voters are expected to receive the highest utility from voting for the party closest to them. In contrast, strategic voting means that citizens support a party other than the most proximal with the intention of influencing the outcome of the election (Blais et al. 2001). Two forms of strategic voting have been identified in the literature. The best known form is when voters are influenced by the perceived electoral chances of parties. Voters may be incited not to support their preferred party because it has weak chances of winning the election (Cox 1997). In other words, citizens should avoid "wasting" their vote by supporting only viable parties. The incentives for such behaviour are typically stronger in majoritarian elections than in PR electoral systems (Cox 1997; Cox and Shugart 1996). As a consequence, much of the literature on traditional strategic voting has dealt with elections hold under majoritarian rules.

"Compensatory voting" is a second form of strategic behaviour that has received some attention in the more recent literature (Adams et al. 2005; Bargsted and Kedar 2009; Blais et al. 2006; Grofman 1985; Kedar 2005). Citizens' choices may also be influenced by their expectations about the government position. They may think about how a weakening or strengthening of the different parties would impact on the policies implemented by the government. Such considerations should be particularly important in PR electoral systems, where governments are often formed by a coalition. No single party can implement its preferred positions fully. The government position is a result of negotiations among the coalition members. This creates incentives for voters to be strategic. Supporting a party other than their preferred party may be the most effective way to keep or move the government position close to their ideal point. Thus, both standard decision theoretic and compensatory / discounting models of voting assume voters to be policy-motivated. But while the former focus on differences between the voters' positions and party platforms, the latter emphasize voters' distances to government policies, which, in the case of coalition governments such as the Swiss, maybe the result of multiparty bargaining.

The incentives for compensatory voting can be illustrated by referring to the example of the 2007 Swiss federal elections. Let us consider the case of a right-wing voter, close to the ideological position of the FDP. The position of the government probably came closer to that citizen's ideal 
point after the 2003 elections, when the SVP won a second seat. If the SVP fares badly in 2007 the CVP may reclaim the governmental seat it lost to the SVP in 2003. This would move the government position back toward the centre. If the SVP defends its share of votes, in contrast, it will probably keep its second seat in the government and the status quo would be confirmed. In this situation, moderate right-wing voters who prefer the status quo to a leftwards shift will be incited to vote for the SVP. This will be the case even if they are, in ideological terms, closer to the FDP than to the SVP. ${ }^{1}$ By a similar logic, centrist voters who wish the government position to move leftwards should be incited to support a left-wing party, i.e., the Social-Democrats or the Greens.

As mentioned, compensatory voting is expected to be stronger in PR elections, which result more frequently than majoritarian elections into a coalition government. Previous research have shown strong evidence for such compensatory voting, particularly in elections where the formation of a coalition government was expected (Kedar 2005, 2006). Incentives for this form of strategic voting are likely to be particularly strong in Switzerland. It is often considered one of the best examples of a consensual democracy (Lijphart 1999), where institutions guarantee that policies are the product of a compromise among many players. Each governmental party has a minority position within the government. Changes in the relative strength of the parties within the government have a much diluted effect on changes in the average governmental position.

Both forms of strategic voting fit into the general definition given above. But they differ in the outcome voters seek to influence and in the origin of the relevant incentives. With traditional strategic voting, citizens try to influence who wins in their constituency (or what the relative strengths of the parties are). The corresponding incentives are created by the electoral chances of the parties at the district level. In the case of compensatory voting, citizens' goal is to influence the government position. The incentives for this lie at the national level and they are thus the same for all voters in a given election. However, their impact on voters' behaviour is still likely to be moderated by constituency specific factors. All voters may recognize that an increase in the vote share of the more extreme parties has a larger

1 The "directional model" of issue voting (Merrill and Grofman 1999; Rabinowitz and Macdonald 1989) would also suggest that a substantial share of citizens should support parties that are more extreme than their own preferences. In that sense, there are similarities between compensatory voting and directional voting. The latter model, however, does not imply strategic behaviour. 
effect on shifting the government position. Supporting a non-centrist party, however, only makes sense if it is viable in one's constituency. In other words, incentives for compensatory voting are conditioned by the incentives not to waste one's vote on a non-competitive party.

The incentives for both forms of strategic voting should be linked to the district magnitude, which varies strongly in Switzerland. ${ }^{2}$ One of the best known results of formal models of party competition under the wasted vote logic is the emergence of local two-party systems in single member districts (SMD), where both competitors converge on the median voter's position (e.g., Cox 1997). If true, the parties that possess high leverage with regards to moving the national government's policy would be exactly those that are, due to their non-centrist ideological positions, unable to win the plurality of votes in SMDs. As the district magnitude rises, in turn, the vote shares required for winning seats declines and the electoral prospects of non-centrist parties improve. Thus, strategic voters in an SMD should be primarily worried not to waste their vote on a hopeless district party (since otherwise they would not be able to influence the national balance of power whatsoever), and vote for a party with plurality appeals. In contrast, strategic voters in larger districts do not have to worry so much about district level viability, and may vote for non-centrist parties capable of moving the national policy status quo into their preferred direction. In linking the rationales from the two literatures on strategic voting, we would therefore expect compensatory voting to increase with rising district magnitude.

\section{Data and Operationalization}

Our dependent variable is a measure of voters' propensity to support a given party. Relying on such voting propensities (y), rather than voting choice, is quite frequent in the framework of spatial models. The analysis focuses on the evaluation of the choice alternatives, rather than on voting choice. This corresponds to a two-stage model of the voting decision process (Rosema 2006; Van der Eijk et al. 2006), where the actual voting choice is preceded by evaluations of the parties in competition. The evaluation stage largely determines the voting decision: Citizens should simply support the party for which they have the highest voting propensity (Van

\footnotetext{
2 Swiss electoral law divides the country into 26 electoral districts (the cantons) ranging from 6 SMDs to multimember districts with 34 seats (Zurich).
} 
der Eijk et al. 2006; see also Steenbergen in this volume). It is thus possible to examine the evaluation stage rather than the choice stage. In doing this, one is still looking at the same decision process. In addition, modeling voting propensities has several advantages (Tillie 1995; Van der Eijk et al. 2006). One of the most important ones is to offer a more rigorous test of the underlying model of voting choice. The hypotheses about the determinants of party preferences are not tested by looking at a simple dichotomy between the party voters supported vs. all other parties. Rather, the expected differences in voting propensities can be tested for all important parties in a given context.

A potential drawback of voting propensities is that they could be less strategic than voting choice itself. The literature on voting propensities argues that these variables include strategic considerations (e.g., Van der Brug et al. 2008; Van der Eijk et al. 2006), but the evidence is rather limited. We cannot exclude that voting propensities are driven primarily by sincere voter preferences, disregarding the strategic considerations we try to capture. However, this also means that we are performing a more conservative test of our hypothesis and it does not undermine the conclusions we may reach if we do observe compensatory voting. ${ }^{3}$

In the 2007 Swiss election study, voting propensities were measured for five to six parties, depending on the canton. Citizens were invited to indicate how likely it is that they will ever vote for each of the corresponding parties. Answers were coded on an 11-point scale, ranging from a "very low probability" to a "very high probability". This variable is recoded to the $0-1$ range. For the present study, the analysis is limited to the voting propensities for the governmental parties, that is, the Social-Democrats (SP), the Christian-Democrats (CVP), the Liberals (FDP) and the Swiss People's Party (SVP). The sample is defined in this way to allow us to focus on compensatory voting among the members of the governing coalition.

The spatial components of the voting choice model are based on citizens' position on the left-right scale and on their perception of parties' posi-

\footnotetext{
3 However, we have also modeled (categorical) party choices using the same set of covariates we subsequently specify in a conditional logit framework, with results quite similar to those presented in Table 1 . The effect of compensatory voting still increases significantly with rising district magnitude, while the effect of proximity voting tends to fade out with rising numbers of seats to be distributed, although this decline is hardly distinguishable from 0 in the conditional logit specification. Detailed results are available from the authors on request.
} 
tion on that same scale. Respondents were asked to locate both themselves and the main parties on an 11-point left-right scale. We have rescaled this item to range from 0 (left) to 1 (right), and use this information to compute both the proximity and compensatory spatial components. The proximity component is based on the squared Euclidean distance between voters and parties. Accordingly, voter $i$ 's utility $U$ from party $j$ is defined as:

$$
U_{i j}^{P}=-\left(v_{i}-p_{i j}\right)^{2}
$$

where $v$ is the voter $i$ 's and $p$ is the party $j$ 's position on an ideological continuum as perceived by voter $i{ }^{4}$ Thus, the utility of $i$ from $j$ so defined increases with decreasing (perceived) distance between voter and party.

Rather than relying on (perceived) party positions, the compensatory component according to Kedar (2005) incorporates the voter's perception of the corresponding party's impact on the government's left-right position:

$$
U_{i j}^{C}=\left(v_{j}-G_{i, j-j}^{*}\right)^{2}-\left(v_{i}-G_{i}\right)^{2}
$$

where $G_{i}$ is the actual left-right position of the government, as perceived by voter $i$. It is defined as:

$$
G_{i}=\sum_{j=1}^{J} w_{j} p_{i j}
$$

where $w_{j}$ is the share of government seats of party $j^{5} G_{i, j^{j}}^{*}$, finally, is the counterfactual position of the government that would result from the exclusion of party $j$, as perceived by voter $i$. It is defined as:

$$
G_{i j}^{*}=\left(\frac{\sum_{l \neq j}^{w_{l} p_{i l}}}{\sum_{l \neq j} w_{l}}\right)
$$

Thus, according to the compensatory voting model, voter $i$ 's utility from voting for party $j$ would increase if the exclusion of $j$ from the government

\footnotetext{
${ }^{4}$ Using voters' perceptions of party positions is the standard procedure in the literature on proximity issue voting (e.g., Adams et al. 2005). It also makes sense from the underlying theoretical model. All voters are not assumed to perceive parties' positions in the same way.

5 In October 2007, FDP, SPS and SVP each held 2 out of 7 Federal Council seats, while the CVP held 1.
} 
moved the government further away from $i$ 's ideal point. Following above reasoning, we would generally expect large amounts of compensatory voting in Switzerland.

Moreover, we would expect the inclination to vote compensationally to increase with rising district magnitude $(M)$, which is naturally measured as the number of seats to be allocated in a district (though we found that a log transformation of district magnitude provided the best empirical fit).The parties' electoral prospects are operationalized in two ways. First, competitiveness (C) is measured using Grofman and Selb's (2009) partyspecific index of political competition for d'Hondt and other parametric divisor rules. ${ }^{6}$ In a nutshell, their index is the inverse of the minimum vote shares required for each party either to win a(nother) or to lose a seat under a worst case scenario, normalized by the threshold of exclusion (that is, the maximum vote share with which it is possible not to win a seat in a district, see Rae et al. (1971). In a Hagenbach-Bischoff district, this is $1 /(M+1)$ ). Its maximum of 1 will obtain if a party is very close to winning a(nother) or to losing a seat; its minimum of 0 will obtain if a party is one threshold of exclusion away from winning or losing a seat. According to traditional tactical voting models based on the district level wasted vote logic, incentives to vote for a party should increase with competitiveness. However, while strategic voting should always work to the detriment of the weak competitors in single member districts, the same is not true for larger districts where additional incentives to desert seat-winning parties chanceless of winning more seats may occur. As there is less reason to expect a strong party that already won seats to be subject to strategic desertion than weak parties that did not win any seats (see Cox 1997), we also include a dummy variable, no seats $(L)$, that indicates whether a party won seats $(0)$ or not (1), along with their interaction.

\section{Empirical Model}

Our dependent variable, voting propensities $y$, may be conceived of as being grouped within $i=1,2,3, \ldots$, Number of observations $=1$ '995 voters (as voters have distinct voting propensities for different parties), within $j=$ $1,2,3,4=\mathrm{J}$ parties (as the four parties receive scores from different vot-

${ }^{6}$ Gauglhofer (1988) demonstrates the mathematical equivalence between the HagenbachBischoff method used in Swiss National Council elections and the d'Hondt method. 
ers), and within $k=1,2,3, \ldots, \mathrm{K}=25$ districts (as each voter is enrolled in a single district). ${ }^{7}$ Each of these factors - voters, parties, and districts - may impinge on the voting propensities due to features not included in our model. For example, an alienated voter may, irrespective of his or her spatial utilities, ascribe lower voting propensities to all of the parties than a satisfied voter; a party may receive lower average voting propensities than its (perceived) spatial location relative to the voters would have one expect, for example, due to unpopular leadership; and finally, the electorate of a district that is not so well integrated into the national political system may, on average, expect lower utilities from all of the national parties than voters from more nationalized districts. However, these factors due not constitute a strict hierarchy. While voters are nested within districts (as no voter is enrolled in different districts), parties and voters as well as parties and districts are so-called crossed factors. To take this complex data structure into account, we set up a cross-classified model with separate error components for each of these factors (see, for example, Rasbash and Goldstein 1994).

$$
\begin{gathered}
\mathrm{y}_{\mathrm{ijk}}=\beta_{0}+\beta_{1 k} U_{i j k}{ }^{C}+\beta_{2 k} U_{i j k}{ }^{C}+\beta_{3} C_{j k}+\beta_{4} L_{j k} \\
+\beta_{5}\left(C_{i j} \times L_{j k}\right)+\mathrm{u}_{1 i}+\mathrm{u}_{2 \mathrm{j}[i]}+\mathrm{u}_{3 k}+\mathrm{e}_{i j k}
\end{gathered}
$$

where the $u$ 's are error terms pertaining to the individual, party, and district level which are assumed to be normally distributed with variances $\sigma_{1}^{2}, \sigma_{2}^{2}$ and $\sigma_{3}^{2}, e$ is an observation specific error term with variance $\sigma_{0}^{2}$, and the $\beta^{2} \mathrm{~s}$ are regression weights. Note that the proximity and compensatory slopes, $\beta_{1}$ and $\beta_{2}$, are additionally indexed with $k$, so that they are allowed to vary randomly across districts, as a function of log magnitude:

$$
\begin{aligned}
& \beta_{1 k}=\gamma_{10}+\gamma_{11} \times \log \left(M_{k}\right)+u_{4 k} \\
& \beta_{2 k}=\gamma_{20}+\gamma_{21} \times \log \left(M_{k}\right)+u_{5 k}
\end{aligned}
$$

where the $\gamma$ 's are regression weights, and the $u$ 's are, again, normally distributed error terms with variances $\sigma_{4}^{2}$ and $\sigma_{5}^{2}$ and correlation $\rho_{45}$. In addition, we also estimate the correlations $\rho_{34}$ and $\rho_{35}$ of the random district deviation $u_{3}$ from the intercept $\beta_{0}$ and $u_{4}$ and $u_{5}$, respectively.

7 The district of Nidwalden held so-called tacit elections in 2007, a euphemism for no election at all, and is therefore excluded from the analysis. 
Table 1: REML-estimates from the Cross-classified Model of Voting Probabilities

\begin{tabular}{lccc}
\hline Fixed part & REML & $S E$ & t-value \\
\hline Intercept & 0.597 & 0.032 & 18.906 \\
Compensatory Component & 0.886 & 0.123 & 7.206 \\
Proximity Component & -0.530 & 0.055 & -9.661 \\
Competitiveness & -0.059 & 0.026 & -2.288 \\
No Seats & -0.145 & 0.038 & -3.825 \\
Competitiveness $\times$ No Seats & 0.139 & 0.051 & 2.732 \\
Log District Magnitude & -0.013 & 0.009 & -1.440 \\
Log Magnitude $\times$ Compensatory & 0.383 & 0.057 & 6.683 \\
Log Magnitude $\times$ Proximity & 0.039 & 0.024 & 1.575 \\
\hline Random Part & Std. Dev. & \multicolumn{1}{c}{ Correlations } \\
\hline Voters & 0.001 & & \\
Districts & 0.027 & & \\
$\quad$ Compensatory Slope & 0.125 & 0.406 & \\
Proximity Slope & 0.056 & -0.975 & -0.195 \\
Parties & 0.035 & & \\
Residual & 0.289 & & \\
\hline
\end{tabular}

\section{Statistical Results}

Table 1 presents residual maximum likelihood (REML) estimates from the cross-classified model of voting probabilities. As to the fixed part of the model, ${ }^{8}$ both the compensatory and the proximity components exert a significant effect on the voting probabilities in the expected direction. An additional ANOVA type of analysis with fixed effects for voters, dis-

\footnotetext{
8 A series of Chi-square tests of the random part indicated that the inclusion of the random party intercepts significantly improved the model fit at $p<0.01$, the inclusion of the district intercept at $\mathrm{p}<0.10$, while the inclusion of the voter intercept did not improve model fit at conventional levels of significant. That is, no unobserved voter characteristics (such as alienation) seem to uniformly affect the voting propensities for all the parties in all of the districts. On the other hand, the inclusion of random slopes for both the compensatory and the proximity component significantly improves model fit at $\mathrm{p}<0.01$.
} 
Figure 1: Estimated Proximity and Compensatory Voting Slopes versus (log) District Magnitude, along with the District Level Regression Lines (Vertical Lines Represent 90\%Confidence Intervals)

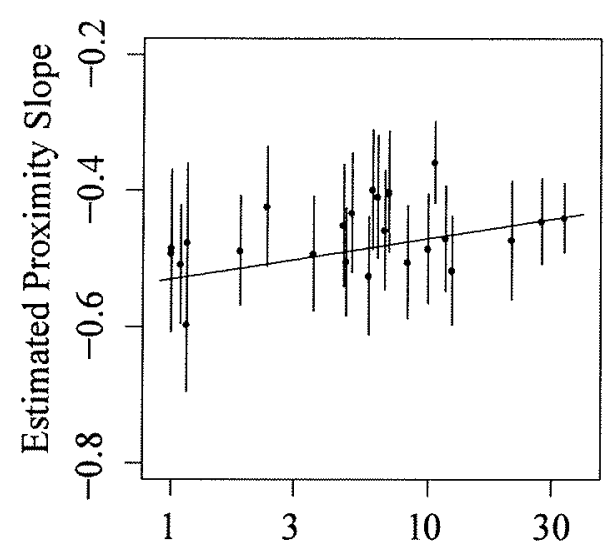

District Magnitude (log scale)

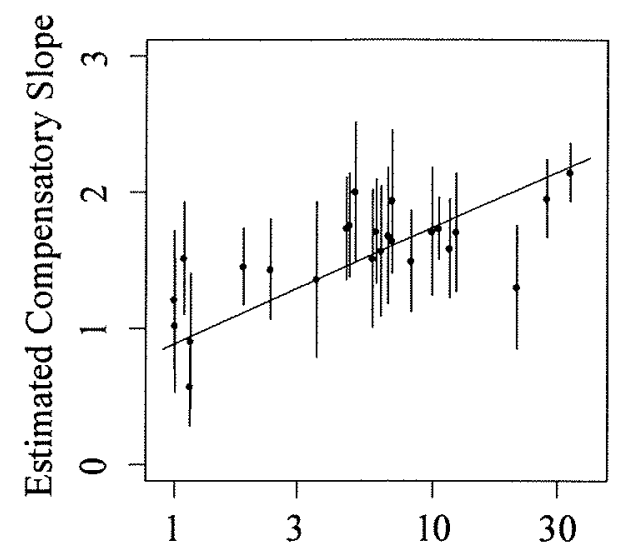

District Magnitude (log scale)

tricts and parties, which is not reported in detail here, ${ }^{9}$ indicated that, in general, the proportion of variance in voting propensities that is due to the compensatory component $(0.15)$ outweighs the proportion of variance accounted for by proximity voting $(0.06)$ by a factor of 2 . Also in line with our expectations, the effect of the compensatory component significantly increases with rising district magnitude, while the effect of the proximity component tends to decrease. This conditional effect is further illustrated in Figure 1, which plots the estimated compensatory and proximity slopes $( \pm 1.645$ standard deviations) versus log district magnitude, along with the district-level regression lines.

Among the single member districts, voters in Obwalden (OW) exhibit a significantly higher amount of compensatory voting than the district level model would have expect (right-hand panel of Figure 1). Recalling the specific situation in this canton during the run up to the 2007 National Council elections - the SVP candidate who eventually won the seat by a very small margin benefited from a coordination failure within the moderate camp - this does not come as a surprise. However, if we look at the

\footnotetext{
9 In our model specification including random proximity and compensatory voting slopes, the decomposition of variance hinges on the covariates in quite a complicated manner. In particular, the proportion of variance explained by the two components is a function of $(\log )$ district magnitude. Therefore, the ANOVA findings reported here should be taken with a grain of salt.
} 
Figure 2: Party-specific Levels of Competition versus (log) District Magnitude

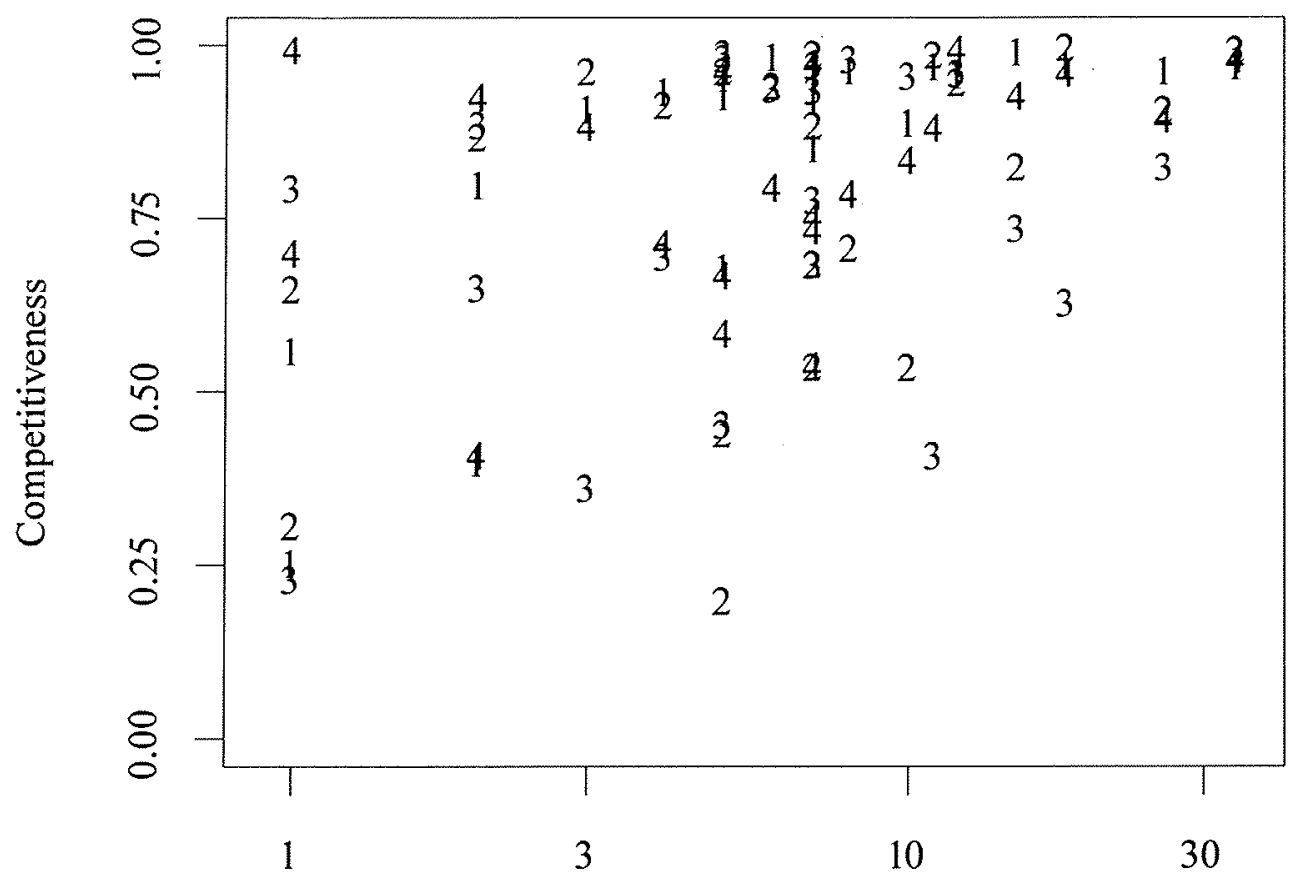

District Magnitude (log scale)

Note: FDP (1), CVP (2), SPS (3), SVP (4).

levels of competitiveness of all the parties in Figure 2, it is obvious that the same holds true for other small districts as well. Contrary to the classical prediction of centripetal party competition in single member districts, we observe that both non-centrist parties were, on average, as competitive as the moderate parties in the single member districts. Further inspection of our data reveals that this is not owing to the possibility that non-centrist parties may field candidates closer to the median voter in small districts, and are thus perceived less extreme (see Figure 3 ). These descriptive finding basically lever out the presumed causal mechanism underlying the empirical relationship between district magnitude and extent of compensatory voting: Lower levels of compensatory voting in smaller districts just does not seem to be a consequence of non-centrist parties having worse electoral prospects in these districts as compared to larger districts! The fact that voters actually do take the parties' competitiveness into account when assigning their utilities - parties that did not win seats receive lower 
Figure 3: Mean Perceived left-right Positions of the Parties versus (log) District Magnitude

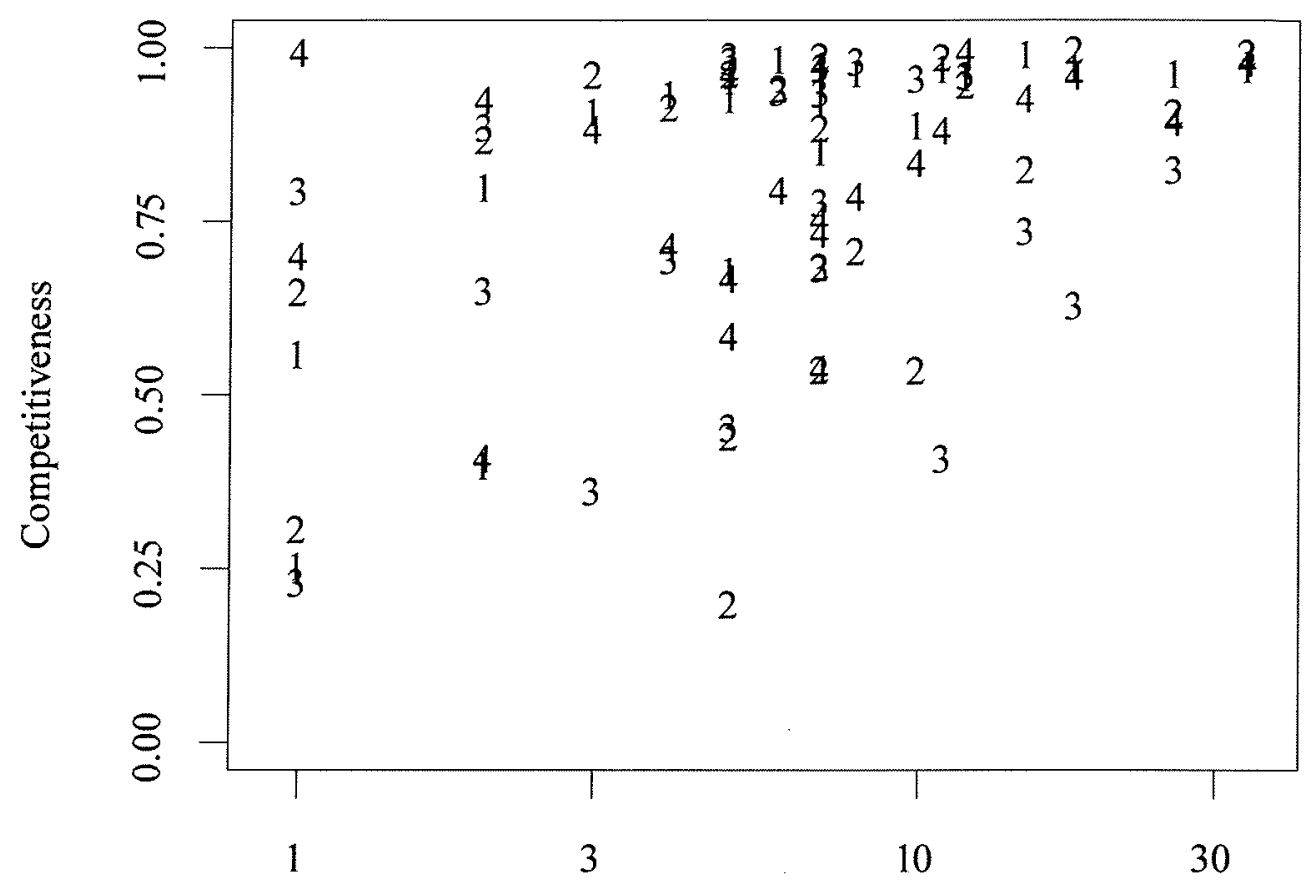

District Magnitude (log scale)

Note: FDP (1), CVP (2), SPS (3), SVP (4).

average voting propensities, and a party's competitiveness has a positive effect given that party has not won any seats - does not alter this puzzling conclusion.

\section{Discussion}

This article as presented several important findings that shed new light on the recent developments in Swiss politics. First of all, the analyses have revealed that compensatory voting is strong among Swiss citizens. Voting propensities appear to be much more strongly influenced by a compensatory component than by traditional proximity voting. Citizens do not simply support the party whose electoral platform is closest to their own preferences. Rather, they discount these policy positions, accounting for the fact 
that parties will have to compromise with the other governmental parties. Voters are ready to support parties they may view as too extreme, because they know their impact on the government position will be only marginal. This means that the polarization of the party landscape largely exaggerates the polarization among voters.

Second, this study has shown that the strength of compensatory voting increases with district magnitude. We expected such an interactive effect, based on the idea that the more extreme parties are less competitive in small districts. The incentives linked with the two forms of strategic voting, thus, should tend to cancel each other out in small cantons. These results also present something of a puzzle, though. While the hypothesis seems to be confirmed, the cantonal decomposition of parties' competitive situation did not reveal such a clear relation between district magnitude and electoral chances of non-centrist parties. The SVP, on which most of the discussion on the polarization trend focuses, is competitive in virtually all cantons, large and small. The lesser degree of compensatory voting in smaller cantons cannot thus be brought back to the SVP being less competitive.

What accounts then for this moderating effect of district magnitude? Our analyses do not deliver a clear-cut answer. Some possibilities seem worth exploring though. An alternative interpretation of why compensational voting increases with rising district magnitude involves information requirement. In particular, MacDonald et al. (1995) emphasize that proximity voting is informationally quite demanding. The complexity of the choice voters have to make may further be related to district magnitude, as citizens in larger districts are usually confronted with a more complex party system.

Another direction in which to extend this research is the specification of the compensatory voting model. In following Kedar's model quite strictly, we might have failed to adequately capture the counterfactuals on government policy that are relevant for Swiss voters. In particular, the Kedar model specifies voter utilities in terms of the difference in government policies in the bare presence and absence of a respective party. But as we know, such all-or-nothing scenarios are quite unrealistic in Swiss politics. Therefore, one might suspect it is more appropriate to think about counterfactuals in terms of the probability of specific government reshuffles. For example, in 2003, it was hardly surprising that an eventual seat gain of the SVP in the Federal Council would be at the expense of the CVP (as the CVP received the smallest fraction of votes, after a pronounced downward trend). Considering statements of party officials and pundits of Swiss politics during 
the run up to the 2007 national elections, the most likely scenarios would probably have been the SVP losing a government seat (namely, Christoph Blocher's) in favour of the CVP, or a seat loss of the FDP in favour of the CVP. To be sure, we have also played around with such alternative scenarios in operationalizing the relevant counterfactuals. However, Kedar's simple specification by far outweighted our more informed alternatives in terms of predictive power. Nevertheless, more efforts should probably be made in order to take the probabilities of particular government formations into account.

\section{References}

Adams, J., Merrill III, S. and B. Grofman (2005). A Unified Theory of Party Competition: A Cross-National Analysis Integrating Spatial and Behavioral Factors. Cambridge: Cambridge University Press.

Bargsted, M. and O. Kedar (2009). Coalition-Targeted Duvergian Voting: How Expectations Affect Voter Choice under Proportional Representation. American Journal of Political Science 53(2): 307-23.

Blais, A., Aldrich, J., Indridason, I. and R. Levine (2006). Do Voters Vote for Government Coalitions? Testing Downs' Pessimistic Conclusion. Party Politics 12(6): 691-705.

Blais, A., Nadeau, R., Gidengil, E. and N. Nevitte (2001). Measuring Strategic Voting In Multiparty Plurality Elections. Electoral Studies 20(3): 343-52.

Cox, G. (1997). Making Votes Count: Strategic Coordination In The World's Electoral Systems. Cambridge: Cambridge University Press.

Cox, G. and M. Shugart (1996). Strategic Voting Under Proportional Representation. Journal of Law, Economics, and Organization 12(2): 299-324.

Gauglhofer, M. (1988). Analyse der Sitzverteilungsverfahren bei Proportionalwahlen. Chur: Rüegger.

Grofman, B. (1985). The Neglected Role of the Status Quo in Models of Issue Voting. The Journal of Politics 47(1): 230-37.

Grofman, B. and P. Selb (2009). A Fully General Index of Political Competition. Electoral Studies 28(2): 291-96.

Kedar, O. (2005). When Moderate Voters Prefer Extreme Parties: Policy Balancing in Parliamentary Elections. American Political Science Review 99(2): 185-99. 
- (2006). How Voters Work Around Institutions: Policy Balancing In Staggered Elections. Electoral Studies 25(3): 509-27.

Lijphart, A. (1999). Patterns of Democracy: Government Forms and Performance in Thirty-Six Countries. New Haven: Yale University Press.

MacDonald, S., Rabinowitz, G. and O. Listhaug (1995). Political Sophistication And Models Of Issue Voting. British Journal of Political Science 25(4): 453-83.

Merrill III, S. and B. Grofman (1999). A Unified Theory of Voting: Directional and Proximity Spatial Models. Cambridge: Cambridge University Press.

Rabinowitz, G. and S. Macdonald (1989). A Directional Theory of Issue Voting. American Political Science Review 83(1): 93-121.

Rae, D., Hanby, V. and J. Loosemore (1971). Thresholds Of Representation And Thresholds Of Exclusion: An Analytical Note On Electoral Systems. Comparative Political Studies 3: 479-88.

Rasbash, J. and H. Goldstein (1994). Efficient Analysis Of Mixed Hierarchical And Cross-Classified Random Structures Using A Multilevel Model. Journal of Educational and Behavioral Statistics 19(4): 337-50.

Rosema, M. (2006). Partisanship, Candidate Evaluations, And Prospective Voting. Electoral Studies 25(3): 467-88.

Tillie, J. (1995). Party Utility and Voting Behavior. Amsterdam: Het Spinhuis.

Van der Brug, W., Franklin, M. and G. Tóka (2008). One Electorate Or Many? Differences In Party Preference Formation Between New And Established European Democracies. Electoral Studies 27(4): 589-600.

Van der Eijk, C., van der Brug, W. Kroh, M. and M. Franklin (2006). Rethinking The Dependent Variable In Voting Behavior: On The Measurement And Analysis Of Electoral Utilities. Electoral Studies 25(3): 424-47. 


\section{Le vote stratégique d'ajustement lors des élections au Conseil National}

Le succès de l'Union Démocratique du Centre et les pertes des partis centristes au cours de la dernière décennie ont nettement renforcé la polarisation du système de partis suisse. Cet article suggère que ces développements sont dus en partie au comportement stratégique de l'électorat. Les politiques gouvernementales sont le résultat de négociations institutionnalisées entre partis, qui sont forcés d'accepter certains compromis. Les électeurs peuvent être incités à compenser cet effet modérateur en soutenant des partis plus extrêmes que leurs préférences personnelles. Cet article examine l'ampleur du vote compensatoire lors des élections du Conseil National de 2007, en se basant sur les données de l'enquête Selects. Les résultats montrent que le vote compensatoire est en général plus important que le vote basé sur la proximité idéologique et que son intensité augmente avec la taille des circonscriptions électorales.

\section{Strategisches Übersteuern bei Nationalratswahlen}

Der Aufstieg der SVP auf Kosten der bürgerlichen Parteien hat innerhalb der letzten Dekade zu einer deutlichen Polarisierung der Schweizerischen Parteienlandschaft geführt. Hier wird argumentiert, dass diese Entwicklung zumindest teilweise das Ergebnis von strategischem Verhalten seitens der Wählerschaft ist: Unter der Zauberformel ist keine der Regierungsparteien in der Lage, ihre Programmatik 1:1 durchzusetzen. Dieser Umstand schafft selbst für moderate Wähler Anreize extrem zu wählen, um die Regierungspolitik gegen die Widerstände der Konsensinstitutionen in die von ihnen präferierte Richtung zu bewegen. In diesem Artikel nutzen wir Selects-Daten, um Ausmass und Bedingungen solch kompensatorischen strategischen Wählens bei den Nationalratswahlen 2007 empirisch zu testen. Unsere Ergebnisse legen nahe, dass kompensatorisches Wählen gegenüber ernsthaftem ideologischem Wählen generell dominiert und mit steigender Wahlkreisgrösse zunimmt. 
Romain Lachat is a senior research associate in political science at the University of $\mathrm{Zu}$ rich. His work focuses on comparative electoral research and electoral institutions. He is particularly interested in the effects of the political and institutional context on the voting decision process.

Address for correspondence: Institut für Politikwissenschaft, Universität Zürich, Seilergraben 53, CH-8001 Zürich, Switzerland. Phone: +41 (0)44 634 39 79; Email: mail@romainlachat.ch.

Peter Selb is a junior professor of political methodology at the Department of Politics and Management, University of Konstanz. His research interests include political behaviour and comparative politics. Recent publications have appeared in Comparative Political Studies, Electoral Studies, European Journal of Political Research, European Political Science Review, Journal of Legislative Studies, Party Politics, Political Behavior and Public Choice.

Address for correspondence: Fachbereich Politik- und Verwaltungswissenschaft, Universität Konstanz, Box D-85, D-78457 Konstanz, Germany. Phone: +49 753188 2321; Email: peter.selb@uni-konstanz.de. 